\title{
GEÇ KAPİTALİZMDE SANATIN ÖZERKLİĞİ VE SANATÇININ İTAATSİZLİĞİ MÜMKÜN MÜ? SANAT NESNESI, SANATÇI VE SERMAYE İLIŞKISISINI ANLAMA DENEMESI
}

\author{
IS IT POSSIBLE FOR ARTIST TO BE AUTONOMOUS OR \\ DISOBEDIENT IN LATE CAPITALISM? AN ATTEMPT TO \\ UNDERSTAND THE RELATIONSHIP AMONG ARTIST, ARTWORK \\ AND CAPITAL
}

\section{İ. Begüm KÖSEMEN ${ }^{*}$}

\section{Özet}

Bu çalışma, sanatın içindeki, sanat yapıtına içkin olan "şeyi” anlamamıza yardımcı olacak tanımlarına değinerek, sanatın politik var oluşunu sorgulayarak sermayeyle olan ilişkisine odaklanacaktır. Piyasalaşmanın yarattığı yeni kurumsal düzen ile bu düzene destek veren mekanizmalar, sermaye ve aktörleri irdelenmeye çalışılacaktır. Ancak en önemlisi, sanat nesnesinin üreticisi olarak sanatçının bu süreçteki rolü ve sorumluluğu sorgulanacaktır. Bu çalışma, kapitalist sanat çağında belli bir kuruma, kişiye ya da iktidara karşı sanatçının politik duruşu üzerinde durarak, sanatçılar için alternatif üretim biçimlerinin bulunmasının zorunluluğunu ve kaçınılmazlığını ortaya koymayı amaçlamaktadır.

Anahtar Kelimeler: Sanat Üretimi, Sanatta Özerklik, Kültür Endüstrisi, Sembolik Sermaye, Neoliberalizm, Kapitalizm

JEL Sınıflandırması: Z10, Z11, E7, P16

\section{Abstract}

This study will focus on the relationship between the art and the capital by questioning the political existence of art by referring to the definitions in art that will help us to understand the inherent "thing" in the work of art. The new institutional order created by marketization and the mechanisms, capital and actors that support this system will be studied. But most importantly, the role and responsibility of the artist in this process will be questioned as the producer of the art object. This study aims to reveal the necessity and the inevitability of finding alternative modes of production for the artists by focusing on his/her policy stance against a certain institution, person or power in the age of capitalist art.

* Dr. Öğr. Üy. Marmara Üniversitesi, İktisat Fakültesi, İktisat Bölümü, begum.kosemen@marmara.edu.tr, Orcid Id: 0000-0003-4997-508X 
Keywords: Production of Art, Authority of Art, Culture Industry, Symbolic Capital, Neo-Liberalism, Capitalism

JEL Classification: Z10, Z11, E7, P16

\section{Giriş}

Sanatın türlü tanımı yapıldı, yapılmakta ve yapılacak; sanat alanından olsun olmasın, birçok düşünür sanatın ne olduğunu anla(t)ma ihtiyacı hissediyorlar; sosyologlar, felsefeciler, tarihçiler hatta artık iktisatçılar sanat nesnesi denen "şey"in büyüsünü sorguluyorlar. Ve işte hâlâ sorgulamaktayız. Peki ama neden? Neden sanat çokça disiplinin anlamaya/anlamlandırmaya uğraştığı bir alan? Hepimizi bu noktada birleştiren şey nedir? Platon’un poesis kavramından, Kant'ın güzeline, Benjamin'in söz ettiği auradan, Klee’nin genesisine birçok kavramdan yararlanarak, yaratımdaki o mistik güdüyü kavramayı deniyoruz. Bir bakıma o güdüyü kavrarsak, o nesnenin değerleniş biçimini de anlayabileceğimizi düşünüyor olabiliriz. Belki bu alanı bu denli çekici kılan şey de budur: Sanatın değerlenme halinin, hızının ve buna etki eden değişkenlerin tahmin edilemezliğii... Kuşkusuz artık çağdaş sanat adı altında kategorileştirilebilen alanın, kapitalist sistemin dinamikleriyle birlikte hareket ediyor oluşu da bu alana merakı ve ilgiyi artırıyor.

Öncelikle şunu ifade etmek isterim ki, çok geniş bir alan olan sanatın birbiriyle bağlantılı olsa da, birbirinden oldukça farklı birçok alt-alanı bulunmaktadır. Bu çalışmada zaman zaman tüm bu alanlardan örnekler verilecek olsa da, çalışmanın ana eksenini çağdaş sanat ve resim olușturacaktır.

\section{Sanatın Tanımı ve Amacı}

Sanatın bildik ve yaygın tanımlarına girmektense, tüm nesneler içinde sanat nesnesini farklı kılan ve sadece ona içkin olan "şey"i açıklayan, ilki yüzyıl önce, diğeri de henüz yeni gerçekleşmiş iki olayla sanatın tanımını sorgulamak isterim. İlk olay, 1911 yılında Paris'te Louvre Müzesi’nden kaçırılan Leonardo da Vinci’nin ünlü Mona Lisa tablosuna dair: Mona Lisa’nın kaçırılışı öyle büyük bir ilgi uyandırır ki, müzenin önünde haftalarca (?) süren kuyruklar oluşur. Ortada eser yoktur, eserden kalan boşluk vardır. Ve eserden kalan boşluğu görmeye gelen yüzlerce insan... Ardından Mona Lisa bulunur. Ancak hikaye bununla da bitmez, çünkü eser artık çok daha meşhurdur. İtalya’nın çeşitli yerlerinde, ABD ve Japonya’da sergilenmesine karar verilir. Dünyada öyle büyük bir rağbet görür ki, resme bakma süresi dakikayla hatta bazı ülkelerde saniyelerle kısıtlanmak zorunda kalınır ${ }^{1}$.

Diğer olay ise Ekim ayının başında Londra Sotheby’s Müzayede Evi’nde yapılan müzayedede gerçekleşmiştir. Kimliğini hâlâ gizli tutmayı becerebilen, ünlü sokak ve grafiti sanatçısı Banksy, Balonlu Kız adlı işinin çerçevesinin içine yerleştirdiği bir düzenekle, satışının - 1.4 milyon dolara

1 Leader, D. (2004). Mona Lisa Kaçırıldı - Sanatın Bizden Gizledikleri, çev. Handan Akdemir, İstanbul: Ayrıntı Yayınları, s.11-14. 
- gerçekleşmesinin hemen ardından, işin kağıt imha makinesinden geçirilerek parçalanmasını sağlamıştır. Ertesi gün eserin değerinin iki katına çıktığı ifade edilmiştir².

İlk durum çok çarpıcıdır; çünkü eser orada olduğu için değil, tam tersine orada olmadığ 1 için değerlenmesi söz konusudur. Bir nesneden kalan boşluğun sergilendiği başka bir nesne düşünebilir misiniz? O halde bu nesneyi herhangi bir nesne olmaktan çıkaran nedir? Ressamı mıdır? Sergilendiği mekan mıdır? Sahibi midir? Onu dolaşıma sokanlar mıdır? Eserin konusu mudur? Güzel olması mıdır? Renkleri ya da boyutu mudur? Diğer yandan izleyiciyi o boşluğu görmeye ikna eden neden nedir? Yaratılmış olan sansasyon mudur? Tanık olma arzusu mudur? Kitlesel bir yönelim midir?

Bütün olan bitenin bir senaryonun parçası olup olmadığı söylentileri bir yana, ikinci durum da oldukça çarpıcıdır. Bir sanatçının kendi işini satışıyla neredeyse eşanlı olarak ve ona temas etmeden parçalamasının dünyada örneği görülmemişti. Olayın çok ünlü ve haliyle çok güvenlikli bir müzayede evinde "canlı olarak" gerçekleşmesi kuşkusuz durumu daha da ilginç hale getirmektedir. Buradaki durum ilk durumdan farklıdır; sanat nesnesi oradadır. Ama eserin değerini artıran şey eserin kendi kendini yok etmesi girişimidir ve olaya neden olan kişi de birebir kendi üreticisidir. Bu nesneyi ertesi gün ederinin iki misline çıkaran (ve hatta bu vesileyle sanatçının tüm eserlerinin değerini artıran) şey nedir? Parçalanmış halinin sağlam halinden daha değerli olduğu başka bir nesne düşünebilir misiniz? O halde soru yine aynıdır: Bu nesneyi diğerlerinden ayıran nedir? Eserin 1.4 milyon dolara satılmış olması mıdır? Üzerine çıan haberler midir? Banksy’nin anarşist eylemlerinin kitleleri gülümseten muzipliği midir? Açık artırmada satılıyor oluşu mudur?

Bunların her birinin etkisi olduğu söylenebilirse de, hiçbiri tam olarak açıklamaya yetmiyor. Konu sanat nesnesi olduğuna göre, estetik yargıdan bağımsız düşünülemez. Belki de bu nedenle yüzyıllardır güzeli, iyiyi ya da hakikiyi tanımlayarak ona varmaya çalışılıyor. Sanat nesnesi güzel olan mıdır? Peki güzel; iyi, yararlı ya da doğru olan olabilir mi? Kant’’ diğer Antikçağ filozoflarından farklılaştıran 'güzel'i tüm bu kavramlardan ayırmasıdır: Kant’a göre, güzel dediğimiz nesne, gerçekleştirilmesi beklenen belirli bir amacın nesnesi değildir, herhangi bir amaçtan tamamen bağımsızdır. Güzelin kendi dışında bir amacı yoktur, dolayısıyla güzeli belirleyen hoşlanma tümüyle çıkarsızdır. Kant güzelin analizinde, güzellik yargısını dört işleve indirger ${ }^{3}$ :

1) Nitelik bakımından çıkarsız hoşa giden şeydir.

2) Nicelik bakımından herkesin hoşuna giden şeydir.

3) İlişki bakımından kendi dışında hiçbir amacı olmadan hoşa giden şeydir.

4) Modalite bakımından zorunlu olan şeydir.

2 "Banksy Auction Stunt Leaves Art World in Shreds", https:/www.theguardian.com/artanddesign/2018/oct/06/banksy-sothebys-auction-prank-leaves-art-world-inshreds-girl-with-balloon, (Erişim tarihi: 12.10.2018)

3 Kant,I. (2011). Yargı Yetisinin Eleştirisi, çev. Aziz Yardımlı, İstanbul: İdea Yayınları, 2. Baskı, s. 46. 
Kant’a göre güzel ile sanat da şurada birleşiyor: ikisi de kendi içsel amacına ve yasallığına ve dolayısıyla kendi başına var olma hakkına sahiptirler" ${ }^{4}$ onların amacı bizzat kendileridir. Ortaya çıkan estetik nesne bir yandan duyusal olmak duyulara hitap etmek zorundadır, çünkü o bireyse, somut, "biricik" olmalıdır, yani duyulara sunulan gerçek bir şey olmalıdır. Öte yandan o, aynı zamanda zihinsel bir oluşum nesnesi olmalıdır. Güzel, neyin tasarımlandığında değil, fakat o şeyin tasarımlanma tarzında bulunur. Yani somut olanın; fiziksel olan nesnenin doğrudan bir rolü yoktur. Estetik duyguyu da uyandıran, nesnenin algılanışında zihne çarpan özel görsel duyumlar ve örüntülerdir ${ }^{5}$. Dolayısıyla, estetik deneyimin nesnesi, hem daha önceden görülmemiş, yepyeni hem de doğrudan karşılaştı̆̆ımız değil de hayal gücünün şekillendirdiği bir şeydir. Yani tüm bilinçli belirlemelerden bağımsız ve öznel bir deneyimdir ${ }^{6}$.

Sanat eseri güzelin taşıyıcısı ve bu güzele yol açan şey olarak bilinçli insan niyeti ve becerisinin bir ürünüdür7 ${ }^{7}$. Doğadaki güzelden farkı da budur. Burada Kant'n mekanik ve estetik sanat ayrımına da geliyoruz: Mekanik sanat, belirli bir amaç için yararlı bir şey meydana getirme niyeti taşırken; estetik sanat kendi adına doğrudan hoşlanma veren şey meydana getirme niyeti taşır. Güzel sanat ise estetik sanatın içinde yer alır. Güzel sanatın, özgür sanat olduğunu iddia eder Kant ve ona kendi başına ve kendisinden ötürü haz veren bir uğraş olarak bakar. Mekanik sanat, bir iş gibi değerlendirilir ve dolayısıyla öğrenilebilir, tekrarlanabilir ve yeniden üretilebilirken; güzel sanattaki "tasarı" ve onda cisimleșen "yapma" ne öğretilebilir, ne de tekrarlanabilir. Yaratım bir defalık, eser biriciktir"

Sanat eserini tanımlayan şey, "kendisi için amaçılı" olmasıdır ki bu otonomi anlamına gelir. Sanat nesnesinin farkı da bu olabilir: Onun kendinden/içsel bir değeri vardır. Buradan hareketle, Kant eserin yaratıcısının da eserin varoluşundan başka hiçbir amacı taşımadığını ifade eder. Ancak sanatçı doğada içgüdüsel olarak yaratım yapandan da farklıdır: Çünkü sanatın kendine yeten ve ona kalıclık sağlayan gerçekliğini yaratan sanat üreticisi, imgeleminde eserini önceden tasarlamıştır. Bunu Marx ve Engels şöyle dile getirmektedir: "Balarısı peteğiyle birçok mimarı utandırır. Ama en kötü mimarı, en iyi balarısından ayırt eden şudur: Mimar yapısını gerçeklikte kurmadan önce imgeleminde kurar. Her emek sürecinin sonunda, emekçinin imgeleminde başlangıç halinde önceden var olan bir sonuç elde edilir”"

Demek oluyor ki kendinden içsel bir değeri olan, amacı kendi olan otonom bir nesne ile karşı karşıyayız. Güzel olma amacı taşımayan, ancak kendisinden ötürü hoşa giden bir nesne bu. $\mathrm{Bu}$ nesneyi üreten yani sanatçı dediğimiz kişi ise, doğadaki canlıların içgüdüsel olarak yaptığından farklı olarak, bu nesneyi önce "tasarlıyor." Bu nesneyi diğer nesnelerden ayıran önemli özelliklerden biri budur. Baudrillard ise bunu nesnenin üretildiği bağlam içinde değerlendirir:

Altuğ, T. (2007). Kant Estetiği, İstanbul: Payel Yayınları, 2. Baskı, s. 48.

Altuğ, s. 60.

Altuğ, s. 63.

Altuğ, s.175-176.

Altuğ, s.179-180.

Marx K. ve Engels, F. (1995). Sanat ve Yazın-I, çev. Ö. Ünalan, İstanbul: Sol Yayınları, s. 125. 
"Bir sandalyeyi (ya da bir et ürününü veya araba kaportası parçasını) sıradan -aynı özelliklerle farklı şekilde yinelenmiş - yapan şey, tüm diğer benzer ya da ufak tefek değişiklikler gösteren sandalyelerin seri bir şekilde üretildiği bağlamdır ${ }^{10}$. Her ne kadar bazı istisnaları olsa da ${ }^{11^{*}}$, sanat nesnesinin seri üretim mantığılla üretilmediği açıktır. Peki bunlar, söz konusu nesneyi bu denli önemli, çarpıcı kılmaya yeter mi? Bir başka deyişle bu önem nereden gelmektedir?

Frankfurt Okulu'nun önemli temsilcilerinden Adorno sanat yapitının öneminin "insanın ümitlerini, isteklerini saklayabildiği alan” olmasından ileri geldiğini ifade eder. Hem sürece, hem an’a dair olduğu için alternatif bir zamansallığı olan, gerçekliği dönüştürme gücüne sahip ve ayrıca topluma muhalif olduğu için toplumsal bir alandır sanat onun için. Adorno'ya göre, sanat çalışması salt Varlık olmaktan çok nesne ve özne arasında bir güç alanıdır ${ }^{12}$.

$\mathrm{Bu}$ güç alanı da nesnenin otonomluğuna ve muhalifliğine sekte vurabilir. Oysa Horkheimer’a göre, sanat özerkliğini koruduğu müddetçe [...] ütopyanın da korunup sı̆̆ındığ son alandır ${ }^{13}$. Marcuse ise "kendisini gerçek yaşamın bir parçası yaptığı ölçüde, sanatın yerleşik düzene muhalif kılan aşkınlığını kaybedeceğini- bu düzene içkin kalacağını, tek boyutlu olup ve böylece bu düzene yenileceğini"14 ifade eder.

Benjamin ise sanat nesnesinin özgünlüğüne dikkat çekerek, söz konusu nesneyi “özgün kılanın, onu çevreleyen kendine özgü aydınlık ve parıltı; hic et nunc (burada ve şimdi) duygusu”"15 olduğunu ifade eder. Dolayısıyla sanattaki bu "yegânelik” ona erişilmezlik özelliği verir ki bu da sanat ürününün hâlesinin (aura) temel öğelerinden biridir ${ }^{16}$. Sanat yapıtının yegâne olması, onu kutsanmış kılar. Sanatı kutsanmış kılan, yani onun aurasını yaratan şey, onun yegâne olmasına bağlı ise, bu yegânelik bozulduğunda, kutsanmışlı̆̆ının yani aurasının da kaybolacağı anlamı çıkmaktadır. Çünkü Benjamin’e göre, "en mükemmel kopyada bile bir şey eksiktir: Sanat yapıtının 'şimdi ve burada' oluşu - bulunduğu yerde bir defalık oluşu. Böylelikle, sanat yapıtının mekanik yeniden üretimi ile yapıta içkin olan özgünlük aranmaz olacaktır, çünkü yeniden üretim sanat yapıtının mevcudiyetine zarar vermemiş bile olsa, yapıtın aurasını bozmuş olacaktır ${ }^{17}$. Benjamin'e göre, modernleşme sürecindeki en önemli olgu da budur; "şeylerin, nesnelerin, sanat ürünlerinin auralarının tahrip olması”. Bu tahribatı, sanayi kapitalizmi döneminde başlayan mekanik yeniden

10 Baudrillard, J. (2004). Gösterge Ekonomi Politiği Hakkında Bir Eleştiri, çev. O. Adanır, A. Bilgin, İstanbul: Boğaziçi Üniversitesi Yayınları, s. 126.

11 Pop Art’ın en önemli temsilcisi Andy Warhol, seri üretimi ve seri üretim nesnelerini kullanarak popüler kültür ve tüketim toplumu ilişkisine dair dolaylı eleştiri üretmiştir. İkiz tablolar üreten bazı ressamlar da mevcuttur. Mesela Rauschenberg'in Factum I ve Factum II adlı tablolarının böyle olduğu iddia edilir (Baudrillard, s. 122-126) Ancak Baudrillard’a göre, ressam birbirinin ikizi olan iki tablo ürettiği zaman bile bunların farklı şeyler olduklarını bilmektedir; zira bunlar iki ayrı zaman dilimi içinde üretilmiş nesnelerdir.

12 Adorno, T. W. (1997). Prisms, Cambridge: MIT Press, 9. Baskı, s.184.

13 Jay, M. (2005). Diyalektik İmgelem-Frankfurt Okulu ve Toplumsal Araştırmalar Enstitüsü’nün Tarihi (1923-50), çev. Ünsal Oskay, İstanbul: Belge Yayınları, 2. Baskı, s. 259.

14 Marcuse, H. (1991). Karşıdevrim ve Başkaldırı, çev: Gürol Koca ve Volkan Ersoy, İstanbul: Ara Yayıncılık, s.93.

15 Jay, s.303.

16 Benjamin, W. (1969). Illuminations, NY: Schocken Books, s.188.

17 Benjamin, s.220-221. 
üretim sürecine ve tabii bu sayede yaygınlaşan meta fetişizmine bağlar. Mekanik yeniden üretim yöntemleriyle birlikte, yeniden üretilmiş nesne hem aurasını ve dolayısıyla özgünlügünü yitirdiği için tarihe tanıklığını kaybedip tarihsizleşmekte, hem de geleceğin dünyasından koparılıp dışarlanmaktadır ${ }^{18}$.

Diğer nesnelerin aynılaşması, başka bir çalışmanın konusuysa da sanat nesnesinin aynılaşmasının ne demektir? Yukarıda sanat yapıtının biricik (yegâne), kendinden amaçlı ve otonom olması, 'şimdi ve burada' duygusu uyandıran bir nesne olması vurgulanmışken, mekanik yeniden üretim ile yeni işlevleri olan bir ürüne dönüşmüştür sanat yapıtt: "Sanat nesnesinin kült değeri yerine sergileme (teşhir) değeri geçmiştir”"19.

Sergileme değeri neyi ifade eder? Bu soruya cevabı tanımlara başlarken saydığım iki çarpıcı örnekle beraber düşünmek isterim. Şimdiye kadar sanat nesnesinin yokluğunda ya da tahrip edildiğinde daha "değerli" oluşunun koşullarını nesnede aradık. Belki de bunun nedenleri nesnede değil de içinde bulunduğu piyasanın özelliklerinde aranmalıdır. Çünkü Mona Lisảnın çalınması örneğinde, Benjamin'in aura ile ifade ettiği 'şimdi ve burada'llk yoktur; çünkü eser yoktur. Diğer durumda Banksy'nin kendi yapıtını satı̧ı sırasında tahrip etmesi örneğinde ise nesne 'şimdi ve buradadır ancak tam değildir. Bu iki örnek bizlere çoğaltılmadan, kopyalanmadan, yeniden üretilmeden şimdi ve burada'nın aksadığı durumlara örnektir. Ancak bu halde bile, değeri düşmemiş aksine artmıştır; sıradanlaşmamış aksine ilgi çekmiştir.

O halde bunu yapan nesne değil, nesnenin içkin olduğu yapıya dairdir. Kant'in şu ifadesini çok anlamlı buluyorum: "Estetik ilgi, nesnenin varoluşuna değil, nesnenin özneyi etkileme biçimine bağlıdır20". Yani aslında en başta verilen iki örnekte belki de odaklanılması gereken; bu nesnelerin nasıl nesneler olduğundan çok, özneler yani bizlerin, içkin olduğumuz piyasa sistemi ve bu sistemin aktörleridir.

Bizleri bunu düşünmeye iten bir başka neden ise özerklik meselesidir. Çünkü sanat nesnesini anlamak için kuşkusuz onun içkin olduğu üretim ve dolaşım koşullarını düşünmemiz gerekir. Sanat nesnesinin kendinden menkul bir anlamı ve amacı olan otonom (özerk) bir nesne olduğu ifade edildiyse de, kapitalist piyasa sisteminin üretim koşullarına tabi kıldığı sanatçının özerk olduğu söylenebilir mi? Weberyan anlamda "kendine ait içsel yasalarla yönetilen değer alanları" özerk sayılmaktadır ${ }^{21}$. Sanatçının nesneyi imgelediği, tasarladığı, henüz o nesne yokken onu imgesel olarak var ettiği yaratım aşamasi; sonra nesneyi "görünür" kıldığı üretim aşamasl; en sonunda ise nesneyi bizzat kendi ya da aracılarla piyasaya çıkardığı dolaşım aşaması olmak üzere üç aşamayı göz önüne alırsak, sanatçının bu aşamalarda özerk olduğunu ifade edebilir miyiz? Peki ya bağımsız? Ya da özgür?

18 Benjamin, W. (1995). Estetize Edilmiş Yaşam - Sanattan Savaş ve Siyasete Alman Faşizminin Kuramları, çev: Ünsal Oskay, İstanbul: Der Yayınları, s.153.

19 Benjamin, s.224.

20 Altuğ, s.64.

21 Menke, C. (2018). Özerkliğin Ötesi, http://www.e-skop.com/skopbulten/ozerkligin-otesi/3813 
Özgürlük konusunda hatırlanacağı gibi, Kant güzel olandan alınan hazzın, çıkarsız ve özgür bir haz olduğunu, çünkü takdir edilmesi herhangi bir çıkar, duyu veya akıl tarafından dayatılamayacağını ifade etmişti; dolayısıyla böylelikle onu yarar ve çıkar üzerine kurulu sanayiden ayırmış olur22 Ancak bu artık gerçekten böyle midir? Bir sanat nesnesinin, bir nesneden ya da bir sanayi malından neden farklı olduğu yukarıda tartışıldı. Ancak günümüzde sanat, söz konusu sanayi malını üreten ticari sermayeden bağımsız düşünülebiliyor mu? Dolayısıyla sanat nesnesinin onaylanması, beğenilmesi veya takdir edilmesi çıkarsız olabilir mi? Özgürlük konusunda Kant’a katılmayan Adornơya göre, "sanatçıların yaşamları gibi, çalışmalarının da yalnızca dişardan bakıldığı sürece özgür görünür ${ }^{23}$ " ve aslında tam da bu yüzden sanat çalışması onun için, nesne ile özne arasındaki iktidar alanıdır.

O halde estetik ilgi, nesnenin özneyi etkileme biçimine bağlı (Kant) ve sanat ürünü nesne ile özne arasında bir iktidar alanı (Adorno) olduğuna göre nesne, özneyi etkilediği ölçüde güçlü olacak, değer kazanacak ve hatta egemen olacak olandır. Özellikle konumuzun belli bir auraya sahip ve nesne olarak kendiliğindenliği, özerkliği olan, biricikliği ile kutsanmış bir sanat nesnesi olduğu düşünüldügünde bu egemenlik daha da çarpıcı bir hale gelmektedir: Çünkü nesnenin mülkiyeti ya da bu mülkiyete aracılık etme - yoluyla bu iktidar alanı da değişmektedir. Artık sanat nesnesinin iktidarındansa; ona sahip olanın, onu piyasaya "kazandıranın", ona yeni bir sahip bulmak için aracılık eden tüm kurumların iktidarı konuşulmakta; sanatçının rolü muğlaklaşmaktadır.

Sanat nesnesinin özneyi etkileme biçimleri kapitalist mübadele sistemi içinde şekillenmektedir. Çünkü kapitalizm içererek dönüştüren dinamik bir yapıdır ve Kapitalizmin yapısal kapanı, zihinsel işleyişi içererek kendini yeniden üretmektedir ${ }^{24}$. O halde diyebiliriz ki, öznenin nasıl bir etkilenim koşullarına tabi olduğunu unutmamak gerekiyor. Çünkü öznelerin nesneyi takdir etme, onaylama, yargılama ya da beğenme koşulları kapitalist sistem tarafından kurum(sal) laştırılmıştır. Peki sanattaki kurumsallaşma nasıl oluşmuştur?

\section{Sanatla Siyasetin Dansı}

"Bizim sanattan anladığımız şey, yani edebiyat, mimari, heykel, dans, tiyatro ve opera gibi tüm güzel sanatları kapsayan sistem 18. yüzyılın ürünüdür ${ }^{25 "}$ der Jusdanis. Yani modern çağda ortaya çıkmış değerler sistemidir söz konusu olan. Aristokrasi döneminde sanatın görevi "mutlakiyetin meşrulaştırılması" iken, Aydınlanma çağında insanlara burjuva kültürü aşılama aracı olmuştur. Daha sonraları ise, kamusal alanın kültürel kurumları, burjuvazinin yeni elde ettiği otoriteyi geçerli kılmanın birer yolu olmuşlardır ${ }^{26}$. Artık ne sarayın, ne kilisenin mülkü olmayan kamusal alanın kültürel mallarına ulaşabilmek kolay olsa da, ne eğitimleri ne de paraları olmayan

22 Artun, A. (2014). Sanatın Özerkliği Üzerine, http://www.e-skop.com/skopbulten/sanatin-ozerkligi-uzerine/1749

23 Adorno, s.184.

24 Ercan, F. (2006). Sermayeyi Haritalandırmaya Yönelik Kavramsal Düzenekler, Praksis, No. 19: 9-53.

25 Jusdanis, G. (1988). Gecikmiş Modernlik ve Estetik Kültür - Milli Edebiyatın İcat Edilişi, çev: Tuncay Birkan, İstanbul: Metis Yayınları, s. 135. 
kitleler, itibar kazanmanın bir yolu olduğunu bilmelerine rağmen bu burjuva piyasasına girmeyi başaramayınca, sanatlar burjuvazinin yetki alanı olarak kalmışıı' ${ }^{27}$. Sanat her bakımdan hem iktidarı, saygınlığı korumanın hem de milli birliğin simgesi olan nesneler, yapılar üreterek geniş kitlelere ulaşmanın faydalı bir yolu olagelmiştir.

Modernite boyunca sanatla siyaset hep iç içe olmuştur. Modernite derken, modern anlamda siyasetin oluşmasıyla başlayan dönem kastedilmektedir; yani ulus-devlete dayalı siyasi iktidar tarzının yaygınlaşmaya başladığı, kökleri 17. yüzyıla dayansa da tam gelişimi 18. yüzyılda gerçekleşmeye başlayan siyaset modeli ${ }^{28}$. Modernitenin köklerinin 17. yüzyıla dayanması özellikle bir kurumla özdeşleştirilebilir: Ulus-devletin beğeni algısını standartlaştırması, hem medeniliğin timsali olarak kendini meşrulaştırması, hem de özellikle resimde olmak üzere konu ve türlere dayanan bir hiyerarşiyle sanat/sanat olmayan yargısını yerleştirmesi bakımından ilk modern kurum kabul edilen Fransız Güzel Sanatlar Akademisidir bu ${ }^{29}$. Sanata neden bu kadar önem atfedildiğine gelince, modernist projenin yerleşmesinde sanatçılar, yazarlar, mimarlar, besteciler, şairler, düşünürler ve filozofların özel bir yeri olduğu yorumu yapılabilir. Bunu Harvey, "sonsuz ve değişmez olan artık otomatik biçimde varsayılmadığına göre, modern sanatçının insanlığın

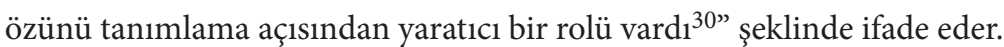

Ulus inşası, geçerliliğininin hâlâ koruyan bir bakış açısıyla, ilk modern siyasi sanat rejimi kabul edilir. Ancak sanatın Devletin sanat kurumlarıla icra ve kontrol ediliyor olması, Fransız Devrimi'yle beraber eleştirilmeye başlanmış ve bir yeni tartışma konusunu gündeme taşımıştır: Sanat için sanat. Théophile Gautier, Mademoiselle de Maupin romanının önsözünü adeta sanat için sanat anlayışının bir manifestosu niteliğinde yazar. Sanatın mutlak biçimde bağımsız olduğunu, ne ahlâka ne de siyasete hizmet ya da itaat edemeyeceğini, araç ya da amaç olamayacağını, sadece kendine hizmet edebileceğini beyan eder ${ }^{31}$.

Sanat için sanat anlayışıyla beraber sanatın özerkliği meselesi daha fazla vurgulanmaya başlanmıştır ${ }^{32}$. 19. yüzyıl sanat siyaset ilişkisi aslında bu eksende gelişmiştir. Başta 1789 Fransız Devrimi’nin etkisiyle beraber, eski rejime bir saldırı gibi görünen ve dolayısıyla sanatta akademik devletçiliğe karşı olan hareket, daha sonra Sanayi Devrimi ve akabinde özgürlükler ve işçi hakları mücadelesi ile gelişen 1848 Devrimi’nde artık evrensel bir şekil almıştır 33: "Paraya dayalı çıkar hesaplarının damgasını vurduğu bencil bir dünya, kitle toplumunun ve kitlesel yoksulluğun

27 Jusdanis, s. 147.

28 Kreft, L. (2008). Sanat ve Siyaset: Sanatın Siyaseti ve Siyaset Sanatı, çev. Elçin Gen, Sanat, Siyaset, Kültür Çağında Sanat ve Kültürel Politika içinde, Ed. Ali Artun, İstanbul: İletişim Yayınları, s.9-49.

29 Kreft, s.23.

30 Harvey, D. (2006). Postmodernliğin Durumu, İstanbul: Metis Yayınları, 4. Baskı, s.31.

31 Ruby, F. (1998). Théophile Gautier et La Question de L’Art Pour L'Art, içinde Bulletin de la Société Théophile Gautier, Montpellier, s.3-5. http://www.theophilegautier.fr/wp-content/uploads/2015/02/BSTG20.pdf (Erişim Tarihi:31.10.2018)

32 Kreft, s.35.

33 Kreft, s.35. 
dünyası, her türlü sahih hayat tarzını tehdit eden sürekli yıkımın dünyası, çirkin ve kalabalık metropollerin dünyasına" karşı bir söylemdir bu artık.

19. yüzyılda Avrupa’da sanatın ne ahlâka, ne siyasete, ne de paraya hizmet etmeyeceğini ifade eden sanatın özerkliğini savunan bu görüş bir yana, bir yandan da oldukça yoğunlaşan bir sanat ortamı söz konusudur; öyle ki özel galeriler, sanat simsarları ve hatta fuarlarla beğeninin şekillendiği yeni bir dönemdir bu. Çünkü Sanayi Devrimi sonrasında Avrupa Devletleri’nde üretimin artması, aynı zamanda yeni pazar ve hammadde ihtiyacını da doğurmuştu ${ }^{34}$. Bu ihtiyacın giderilebilmesi için sanayi ürünlerinin ve üretim araçlarının tanıtılması amacı ile uluslararası sergiler (fuarlar) düzenlenmeye başlanmıştır. Başlangıçta sanayi ve ticari amaçla başlatılan bu sergiler, daha sonraları Avrupa ile Avrupa dışında bulunan devletlerin kültür ve yerel sanatları arasında da etkileşime de sebep olmuştur ${ }^{35^{*} 36}$. Bu uluslararası fuarların ticari etkisi bir yana, sanat anlamında önemli bir etkisi de zenginleşen imalatçı sınıfın çok sayıda resim almaya başlamalarına ön ayak olmalarıdır ${ }^{37}$.

\section{Sanatta İtaatsizlik}

19. yüzyılın bir yandan zenginleşen imalatçı sınıfları, çeşitlenen üretim ortamı ve fiyatı artan başta resim olmak üzere sanat piyasası, bir yandan da bu kapitalist sisteme ve onun anayasal cumhuriyet dünyasına dair radikal bir eleştiri sunan anti-politik görüşü ${ }^{38}$ ile belirlenen ortamı, 20. yüzyılda yerini Avangard Modeli’ne bırakmıştır. Avangard, modernizmi, sanatın özerkliğini hayattan kopuk olduğu için reddeder ve çok daha radikal manifestolarla sanatın sonunu ilan ederek $^{39}$, kendini anti-sanat'la özdeşleştirir, çünkü avangard sanatın meselesi kurumsallaşmış sanattır ve bu yok edilmelidir.

Avangard, modernizmi reddeder, çünkü "modern sanat ne kadar anti gelenekçi olduğunu iddia etse de içten içe gelenekseldir. Modern Sanat, hayat pratiğinden özerkliğini korur ve sanat, kurum olarak kalır" 40 . Modernizmin kendinde bir amaç olarak özerkliği de sorgulanır Avangard sanatta. Modern Sanat, Avangard’ın tersine politik - sosyal bir mesaj verme derdinde de değildir. Toplumsal sorunların farkındadır, fakat bu sorunların bir çözümü olabileceğine dair bir inancı yoktur. Eserin anlamı kendindedir. Bu yüzden de yüksek kültürün bir parçası ve elitisttir ${ }^{41}$.

34 Tekdemir, A. (2013). 1867 Paris Sergisi ve Sultan Abdulaziz’in Sergiyi Ziyareti, Trakya Üniversitesi Edebiyat Fakültesi Dergisi, C.3(6): 1-19.

35 * 1851 yılında başlayan bu evrensel sergilere Tanzimat sonrası çağdaşlaşma hareketinin etkisiyle Osmanlı Devleti de katılmış, hatta 1863 yılında ev sahipliği de yapmıștır. Bkz. Germaner.

36 Germaner, S. (1991). Osmanlı İmparatorluğu’nun Uluslararası Sergilere Katılımı ve Kültürel Sonuçları, Tarih ve Toplum, 16 (95): 33-40.

37 Jusdanis, 148-149.

38 Kreft, s. 35.

39 Bürger, P. (2003). Avangard Kuramı, Çev: Erol Özbek, Şeyda Öztürk, İstanbul: İletişim Yayınları, 2003 , s.104.

40 Huyssen, A. (1981). The Search for Tradition: Avant-Garde and Postmodernism in 1970's, New German Critique, 22(1): 23-40.

41 (R. Murphy'den aktaran) Sorguç, G. (2017). Sanata Karşı Başkaldırı: Avangard, FLSF, Güz, no.24: 37 - 56. 
Daha önceleri yalnızca askerî ve siyasal anlamlarda kullanılan "avangard" terimini sanata kazandıran Saint-Simon'dur. 1830’larda sanayici ve bilim adamlarına şöyle hitap eder"42: “Size öncü olarak hizmet edecek olanlar biz sanatçlarız. Toplum üzerinde olumlu bir etki yaratmak, gerçek kutsal işlev görmek ve düşünsel yeteneklerin en büyük gelişmeyi yaşadığı çağda hepsinin ileri kolu olmak - sanat için ne kadar güzel bir kısmet!” Saint-Simon'un kavramı kullanışından yaklaşık bir asır sonra, Avangard sanat kuramı adeta yeşerir. 20. yüzyılda ömrü iki dünya savaşı arası kadar olan akım, sanata yapılan ilk özeleştiri kabul edilebilir. Sanatı gündelik hayata sokarak toplumu dönüştürmek amacıyla gelişen Dada, sürrealizm, fütürizm gibi avangard girişimler aracılığıyla gerçekleşen bir anti-sanat hareketidir.

Avangard sanatçılar, yayınladıkları manifestolar aracılığıyla hem kapitalist üretim süreci ve biçimlerine, iktidara, savaş çı̆̆ırtkanlarına ve tüm bunlara suskun kalanlara sert cevaplar vermişler ve kendi anlayışlarına göre biçimlendirdikleri sanatçı imgesini çizmişlerdir.

1909'da sadece fütürizmin değil, sanatçı manifestosu fikrinin başlangıcı sayılan Fütürist Manifestoda Marinetti mücadelelerinin kurumlaşmış, ataletle varlığını sürdüren tüm yapılara karşı olduğunu beyan eder. Durağan, hülyalı bir uykuyla yüceltilmiş olan, kokuşmuş, çürümüş ve tutku, manevi bir cömertlikle yapılmayan hiçbir işin başyapıt olamayacağını iddia eder. Ülkenin (İtalya) her yanını kaplayan müzelerin mezarlıklarla aynı şeyi ifade ettiğini savunur ve ikisinin de kimsenin hatırlamadığı kasvetli cesetler topluluğu olduğunu söyler ${ }^{43}$. Bunlara karşı aşırı korumacılığın zararlı olduğunu ifade eden Şöyle sorar Marinetti ${ }^{44}$ :

“Elbette Azizler Günü’nde mezarlıkları ziyaret edercesine yılda bir kez gitmek mümkündür - bunu anlıyorum. Ve yılda bir kez Mona Lisa'nın altına bir çelenk bırakılır - bunu da anlıyorum! Ancak asla müsaade etmeyeceğim şey ise sefaletimizin, o cılız cesaretimizin ve hastalıklı endişelerimizin günbegün bu müzelere sürülmesidir. Neden kendimizi zehirleyelim? Neden çürümek isteyelim?”

Bir sene sonra Fütürist Ressamlar Manifestosu'nda tüm güçleriyle eskimiş olana korkakça tapınmayla, yeniye ve gençliğe dair duyulan adaletsiz nefretle, müzelerin gaddar varlığını teşvik ettiğin geçmişin fanatik, anlamsız ve züppe dini ile savaşacakları ilan edilir ${ }^{45}$.

Dadaistlere geçtiğimizde de onlarca manifestoyla karşılaşıyoruz. Dada’nın adını koyan, hareketin öncülerinden olan Hugo Ball, sanatın ancak tiyatro ile insanı kurtarabileceğini düşünüyordu. Bu düşünceyle Zürih’te (savaşa uzaklığı ve İsviçre’nin tarafsızlığı nedeniyle) ve Kabare Voltaire’i 1916’da hayata geçirdi. Kabare tiyatro yapmak için kurulmuşsa da, örgütlenmenin altında yatan unsurlardan belki de en önemlisi; “ Zürih’e sı̆̆ınmış olan muhalif avangard sanatçıların, edebiyatçıların ve siyasilerin topluca ve özgürce yaratabilecekleri bir ortam oluşturmaktı ${ }^{46}$.

42 (Bell'den aktaran) Harvey, s. 33.

43 Marinetti, F. T. (2017). Fütürizmin Kuruluşu ve Fütürist Manifesto, çev. M. Emir Uslu, Fütüristlerden Stuckistlere 100 Sanatçı Manifestosu içinde, der. Alex Danchev, İstanbul: Espas Yayınları, s.29-35.

44 Marinetti, s.31-33.

45 Boccioni, U. (2017). Fütürist Ressamlar Manifestosu, çev. M. Emir Uslu, Fütüristlerden Stuckistlere 100 Sanatçı Manifestosu içinde, der. Alex Danchev, İstanbul: Espas Yayınları, s.36-39.

46 Altınyıldız Artun, N. ve Artun, A. (2018). Dada Kılavuz: 1913-1923 Münih, Zürih, Berlin, Paris, çev. Nur Altınyıldız 
Açılıştan bir süre önce okunan Edebi Manifesto ile Dadacılar “Tüm 'izm’ler, taraflar ve dünya görüşleri ile boy ölçüşmek, karşı çıkmak istediklerini” ifade ederler ${ }^{47}$. Tüm sözlerin artık olmadığını, söylenegelen her şeye karşı olduklarını beyan eden Dadacılar, Dada Mainfestosu’nda Komünist Manifesto’ya gönderme yaparak, "Dünyanın Bütün Emekçileri Birleşin” sloganını, "Dünyanın Bütün Emekçileri, Dada’laşın” sloganına çevirmeyi önermişlerdir ${ }^{48}$. Yine bir Dadaist olan Hans Arp,

"Bizler, 1914 tarihli Dünya Savaşı̉nın katliamından tiksindiğimiz için Zürih’te kendimizi sanata adadık. Uzaklarda silahlar ateşlenirken tüm gücümüzle şarkı söyledik, resim yaptık, kolajlar yapıp şiirler yazdık. Çağın deliliğine çare olsun diye temellere dayanan bir sanatı ve cennetle cehennem arasında yeni bir denge kursun diye yeni nesneler düzeni arıyorduk. İktidar delisi gangsterlerin, bir gün sanatı insanların zihnini öldürecek bir yol olarak kullanabileceklerine ilişkin bulanık bir önseziye sahiptik ${ }^{49}$ " diye ifade eder.

Sanat tarihçisi David Hopkins’e göre, Dada’nın anti-sanat eylemlerinin genel amacı "şirazesinden çıkmış" modern kültürü en aşırı eylemler aracilığıyla tekrar hizaya sokmak ve Arp’’n dediği gibi çağın deliliğine çare bulmaktır ${ }^{50}$.

Tzara, Dada’nın bir bağımsızlık ihtiyacından ve birlikteliğe dair güvensizlikten doğduğunu ifade ederek, Dada’da özgürlüklerin korunduğunu söyler. Sanatçı gruplarının burjuvanın sanat ortamlarında ya da aynı insanların fon şirketlerinde firsatlar peşinde koşmaları karşısında şunu sormaktan çekinmez: "Sanatın amacı para kazanıp, o tatlı burjuvaziyle sıkı fikı olmak mı?51"

Sadece sanat alanına yönelik değildir başkaldırılar. Savaşın etkisi ve kapitalist üretim süreci sivil hayatı ve çalışma koşullarını da tehdit etmektedir. Bunları durdurmaya yönelik başka bir itaatsizlik çağrısı da özellikle sürrealizm kapsamında retorikleşen "çalışmanın reddi"dir. Kapitalist değer üretimine katılmayı engellemek isteyen bu karşı çıkış, sisteme bir alternatif arayışıdır. Çalışmayı yücelten sistem, bunu esaretle bağdaştıran Breton tarafından sert bir dille eleştirilmiş ve hatta grev önerilmiştir ${ }^{52}$. Benzer şekilde Duchamp da arkadaşlarını üretimin, üretkenliğin ve üreticilerin oluşturduğu efsunlu çemberden kendilerini kurtaran bir "işin reddi”ni düşünmeye ve icra etmeye teşvik eder. Çünkü ona göre, "tıpkı rol ve vazifelerin büyük çoğunluğu gibi sanatçı da bir işverene değil, bir dizi iktidar aygıtına bağlıdır" 53 . Kapitalist mübadele sisteminin yarattığı; tarihte hiç olmadığı çok çalışmak ve giderek daha çok zamanı çalışmaya feda etmektir. Duchamp, teknoloji

Artun ve diğerleri, İstanbul: İletişim Yayınları, s.43-51.

Artun ve Artun, s. 47

Ball, H. (2017). Dada Manifestosu, çev. M. Emir Uslu, Fütüristlerden Stuckistlere 100 Sanatçı Manifestosu içinde, der. Alex Danchev, İstanbul: Espas Yayınları, s.143-145.

Arp, H. (2018). Dadaland, çev. Nur Altınyıldız Artun ve diğerleri, Dada Kılavuz: 1913-1923 Münih, Zürih, Berlin, Paris içinde, der. Nur Altınyıldız Artun ve Ali Artun, İstanbul: İletişim Yayınları, s.66-67.

Hopkins, D. (2006). Dada ve Gerçeküstücülük, çev. Suat Kemal Angı, Ankara: Dost Kitabevi, 2006, s.88.

Tzara, T. (2017). Dada Manifestosu, çev. M. Emir Uslu, Fütüristlerden Stuckistlere 100 Sanatçı Manifestosu içinde, der. Alex Danchev, İstanbul: Espas Yayınları, s. 151-159.

Breton, A. (1925). La Dernière Grève, La Révolution Surréaliste, No. 2 (1-3).

Lazzarato, M. (2017). Marcel Duchamp ve İşin Reddi, çev. Sercan Çalcı, İstanbul: Kolektif Kitap, 2017 , s.11. 
ve icatların insanları bundan kurtaracağına daha da sıkılaştırmakta olduğunu ifade ederek şöyle der: "Sırf yaşamak için hâlâ çalışmak zorunda olmak utanç verici ${ }^{54 "}$. Ona göre ücretli emek, köleliğin en berbat biçimidir. Doğal olarak, tembelliği önerir Duchamp; tembelliğin mübadeleyi sekteye uğratacağını, mülkiyeti ve kullanım hakkını tehdit ederek çökerteceğini dile getirir ${ }^{55}$.

Sanatçıyı da diğer üreticilerden çok farklı görmez. Diğer her faaliyet kadar toplumsal işbölümünün parçası olan sanat da bu sistem içinde belirlenir. Sanatsal üretimin kapitalizmin hızıyla gerçekleşmesini doğru bulmaz ve sanatçılar için de itaatsizlik önerir:

"Sanatsal üretimin reddi, giderek genişleyen kamunun estetik taleplerini karşılamak amacıyla piyasa ve koleksiyoncular için üretmeyi reddetmek demektir. Onların değerlendirme kıstaslarına nitelik ve nicelik taleplerine teslim olmayı reddetmek demektir. Tehlike nihayetinde kapitalist rütbelere kapılmaktır ${ }^{56 ”}$.

Spagetti gibi resim alınan bir dönemde sanatçının egemen tâbi olma biçimlerine bakmak gerekmektedir. Çünkü kralın ya da derebeyin boyunduruğundan kurtulunca özgürleşmemektedir sanatçı. Aksine, bir tâbi kılma biçiminden bir diğerine geçmiştir ${ }^{57}$. Dolayısıyla bu durumda sanat üretiminin tektipleşmemesi, biricikliğin kaybolmaması mümkün değildir.

Sanat manifestoları Avrupa'da 60'larda bürokratik bir hal alan ve korunan sanata karşı olan ve doğrudan yaşanan anın örgütlenmesini önemseyen, başını Guy Debord’un çektiği Situasyonizmi ${ }^{58}$, Amerika'da "Dünyayı bu burjuva entelektüel hastalıktan, profesyonel ve ticari kültürden; bu ölü, yapay sanattan arıtın!” diyen Fluxus ${ }^{59}$ 'u hareketlendirmiştir. Hatta Japonya'da Gutai Hareketi’ne ve Arap dünyasında Arap Sürrealist Hareketi’ne dahi yansımıştır.

Japonya'da 2. Dünya Savaşı ardından ortaya çıkan Gutai, savaşın travmatik yaralarını sarmak için kullanmıştır. Gutai sanatçlları izleyicilerinin pasif birer sanat tüketicileri olmalarına asla izin vermeyecek ve onları sanat üretiminin bir parçasına dönüştürerek kendileri adına düşünmeye, tasarlamaya, üretmeye, kendini özgürce ifade etmeye davet edecektir ${ }^{60}$. Daha sonraları, Japonyảnın hızla ekonomik büyümesiyle ortaya çıkan şirketleşme, robotlaşma ve yabancılaşma karşısında bireyselliği ve yaratıcllı̆̆ harekete geçirmeye ve doğayla uyumlu olarak teknolojiyi kullanmaya yönelik çalışmayı şiar edinmiştir. Grubun lideri niteliğindeki Jiro Yoshihara özgünlük fikrini vurgular; bunu "Daha önce kimsenin yapmadığını yap" şeklinde sloganlaştırır. Yoshihara, "Günümüz algısında, bildiğimiz ölçüdeki sanatlar inanılmaz bir gösterişle döşenmiş kopyalar

54 Lazzarato, s.18.

55 Lazzarato, s.12.

56 Lazzarato, s.21.

57 Lazzarato, s.23.

58 Debord, G. (2017). Sitüasyonist Manifesto, çev. M. Emir Uslu, Fütüristlerden Stuckistlere 100 Sanatçı Manifestosu içinde, der. Alex Danchev, İstanbul: Espas Yayınları, s.351-354.

59 Maciunas, G. (2017). Fluxus Manifesto, çev. M. Emir Uslu, Fütüristlerden Stuckistlere 100 Sanatçı Manifestosu içinde, der. Alex Danchev, İstanbul: Espas Yayınları, s. 367-369.

60 Polat, N. (2017). Sınırları Aşındırmak - Modernizm ve Çağdaş Sanat Üzerine, İstanbul: Belge Yayınları, s.108-109. 
gibi görünmektedir. Gelin bu sahte nesne yığınlarını sunaklarında, saraylarında, salonlarında ve antika dükkânlarında bırakıp gidelim ${ }^{61 " ~ d e r . ~}$

İlk kez 1976'da yayınlanan Arap Sürrealist Manifestosu’nda ise egemen sınıfın büyük değerlerini sorgulanır: Vatan, aile, din, okul, kışla, kilise, camii... Burjuva düzenin baskıcı aklına karşı tüm içgüdülerin serbest bırakılması salık verilir ${ }^{62}$. Sert bir dille yazılan manifestoda, tüm ifade biçimlerini kapitalist karmaşadan ve ticari kazanç güdüsünden serbestleştirme amacı fark edilir.

1960'lar bir yandan dünya savaşları ardından yeniden şekillenen ve kapitalist sistemle iyice giriftleşen üretim ve mübadele ilişkilerinin egemen ile tâbi olanı yeniden tanımladığı yeni bir dünya düzeni, bir yandan da tüm bunların sonucunda ortaya çıkan baskı ve eşitsizlik ilişkilerine direnen yaratıcı ve entelektüel yeni dünyanın hem kendiyle hem de sistemle şiddetli mücadelesi yıllarıdır. Yukarıda bahsedilen manifestolar ve bahsedilmeyen birçok akım bu dönemin küçük bir kesiti gibi yorumlanabilir. Pop art, nouveau réalisme, aksiyonizm, op art, kinetik art, minimalizm, renk alanı resmi, fluxus, happeningler, performans sanatı, kavramsal sanat, anti form, arte povera, land art, beden sanatı vb tüm bu sanat grupları, eğilimler veya akımlar 60'lı yıllarda geçekleşmiştir ${ }^{63}$. Bu hareketli dönem, çağdaş sanatın da başladığ 1 döneme işaret eder ${ }^{64}$. Bunun yanında modernizmden postmodernizme geçişi hazırlayan hareketi hazırlayan koşulları da yaratır. Çünkü 60’ların sonu, kurumsallaşmış iktidar, tekelci güçler, devletlerin baskı rejimlerine karşı anti-otoriter bir tavırla, bireyselleştirilmiş kendini gerçekleştirme alanları üzerinde duran modernizm karşıtı akımların da doğduğu zamandır. 1968 küresel bir isyancılık dalgasının doruğu gibi yorumlanabilir ve hareketin daha sonra ortaya çıkacak olan postmodernizme dönüşün kültürel ve politik habercisi olarak görülmesi gerekir ${ }^{65}$.

\section{Sembolik Sermaye Biriktirme Biçimi Olarak Sanat}

Yani çağdaş sanattan ve postmodernizmden söz ederken yaklaşık yarım asırlık bir geçmişten söz ediyoruz. Çağdaş sanatın ve postmodernizm denen olgunun 1970’ler itibariyle kültür, düşün ve sanat alanına hâkim olması pek tabii ki tesadüf değildir. Çünkü "çağdaş sanatın aynı zamanda bir piyasa olgusu olduğu ve kapitalizmle doğrudan ilişkisinin onun için temel bir belirleyen olduğunu unutulmamalıdır ${ }^{66 " ~ d i y e ~ i f a d e ~ e d e r ~ P o l a t ~ v e ~ e k l e r ~ " c ̧ a g ̆ d a s ̧ ~ s a n a t ~ i c ̧ i n d e ~ k a p i t a l i z m e ~ k a r s ̧ ı ~ u ̈ r e t i l e n ~}$ muhalif sanat bile piyasa içinde güçlü bir ekonomik değerle günümüzde yüklenebilmektedir”.

1980'lerden itibaren sermaye, neo-liberal ekonomi politikaları çerçevesinde uluslarasılaşmanın önündeki tüm engelleri de yutarak, her alanı kendisi için artı-değer yaratıcı bir hale

61 Yoshihara, J. (2017). Gutai Manifesto, çev. M. Emir Uslu, Fütüristlerden Stuckistlere 100 Sanatçı Manifestosu içinde, der. Alex Danchev, İstanbul: Espas Yayınları, s.335-339.

62 Dib, M. ve diğerleri. (2017). Arap Sürrealist Hareketi Manifestosu çev. M. Emir Uslu, Fütüristlerden Stuckistlere 100 Sanatçı Manifestosu içinde, der. Alex Danchev, İstanbul: Espas Yayınları, s. 393-395.

63 Millet, C. (2006). L'Art Contemporain - Histoire et Géographie, Paris: Flammarion, s.27.

64 Millet, s.26.

65 Harvey, s.53.

66 Polat, s.175. 
büründürmüştür. Artık söz ettiğimiz küresel bir kapitalizmdir. Küresel kapitalizmin çağdaş kültür söylemi oluşturma ayağı ise sanatı bir pazarlama aracilığıyla kullanmaya başlayan şirketler yoluyla oluşmaya başlamıştır. 1980'lerin başlarında Amerika ve İngiltere'de iktidara gelen Reagan ve Thatcher yönetimlerinin başını çektikleri özelleștirme politikalarının kültür ve sanat alanına da bu zamanda yansıması tabii ki tesadüf değildir. $80^{\prime}$ lerden itibaren şirketler sanat koleksiyonculuğu etkinliklerini yoğunlaştırdığı gibi, sanat müzeleri ve galerilerini birer tanıtım aracına dönüştürmeye başlamışlardır ${ }^{67}$. Bu anlamda şirketler için sanat sponsorluğunun yasal temelleri atılmış, bunun 70'lerde zedelenen kurum imajının onarımı için “aydın, ilerici, çağdaş" bir şirket kimliği yaratmadaki önemi kavranmıştır. Bir başka ivme de 90'lara girerken kazanılmıştır. Soğuk Savaş่ın bitmesi sanat dünyası için yeni bir değişime neden olmuştur ${ }^{68}$. Artık söz konusu olan küresel kapitalizmle kol kola küreselleşen sanattır ve tabii ki bu beraberinde küresel sanatın kurumlaşması olgusunu da hazırlamıştır. Uluslararası sanat bienalleri, sanat fuarları bunun en güzel örnekleridir.

Kültürel ve sanatsal olmak üzere tüm ideolojik alanlar -da - kapitalist mantığın içinde biçimlenmektedir. Dolayısıyla sanat, sermayenin artı-değer yaratma amacıyla girdiği meta üretimi sürecinden ayrılabilir $\mathrm{mi}^{69^{*}}$ ? Tabii ki, hayır. Ekonomik çıarlara kayıtsız gibi görünen alanlar (sanat, edebiyat, bilim vs.) bile sermaye birikimi ve sermayenin yeniden üretim mantığına göre işlemektedir ${ }^{70}$. Ancak bu alanlardaki çıar, ekonomik alanlardaki gibi apaçık görülmez. $\mathrm{O}$ nedenle bu alanlara giren sermayenin ekonomik olanı daima yadsıması âdettendir. Bourdieu bu durumu "ekonomik olan ne kadar yadsınırsa, çıkar gütmemeye dayalı inanç o kadar yerleşir" şeklinde özetler. Çünkü ekonomik sermaye, alanın sunduğu özgül kârları ve vade sonunda getireceği ekonomik kârları, ancak sembolik sermayeye dönüştüğünde sağlayabilir ${ }^{71}$ ki sembolik sermaye de bilindiği üzere bütün diğer sermaye türlerini (ekonomik, sosyal ve kültürel) içinde barındıran ve bu ölçüde de içinde olunan alanda söz sahibi olmayı sağlayan, tanınmış olmanın sermayesidir.

Sermaye kadar önemli bir kavram da alandır Bourdieu için. Oyun metaforundan yararlanarak açıklar kavramı. Nasıl ki oyunda kartların görece gücü oyuna göre değişiyorsa, farklı sermaye türlerinin hiyerarşisi de farklı alanlarda değişir. Yani oyundaki çok etkili kartlar gibi her alanda geçerli temel sermaye türleri de vardır ancak bunların görece değerleri alanlara göre değişmektedir. Bir sermaye türünün değeri, bu sermayenin kullanabileceği bir alanın (bir oyunun) varlığına bağlıdır. Ve oyuna bağllı̆ğımızı sağlayan şey de, onun getireceği ödüllere sahip olma arzumuzdur. Bir sermaye ya da sermaye türü belli bir alanda hem mücadele silahı, hem de uğruna mücadele

67 Wu, C. (2005). Kültürün Özelleştirilmesi-1980'ler Sonrasında Şirketlerin Sanata Müdahalesi, çev. Esin Soğancılar, İstanbul: İletişim Yayınları, s.16-17.

68 Stallabrass, J. (2009). Sanat A.Ş. - Çağdaş Sanat ve Bienaller, çev. Esin Soğancılar, İstanbul: İletişim Yayınları, s.40.

69 *Bu sanat nesnesinin meta olarak üretildiği anlamına gelmemektedir. Bu çalışmanın konusu olmadığı için bu konuya girilmemektedir. Ancak daha fazla bilgi için Bkz. Kösemen, İ. B. (2012). Nesne ile Meta Arasında Sanat, M.Ü. İktisat Fakültesi Dergisi, 33(2): 205-220.

70 Calhoun, C. (2007). Bourdieu Sosyolojisinin Ana Hatları, Ocak ve Zanaat: Pierre Bourdieu Derlemesi içinde, der. Güney Çeğin ve diğerleri, İstanbul: İletişim Yayınları, s.77-129.

71 Bourdieu, P. (2002). Sanatın Kuralları, çev. N. Kâmil Sevil, İstanbul: YKY, 2002, s.238. 
edilen şey olarak sahibine belli bir iktidar kurma olanağı veren, hem de orada var olmayı sağlayan şey olarak belli bir alanda etkilidir ${ }^{72}$.

Dolayısıyla sermayenin, artı-değeri yadsıyarak, sanat alanına girmesi alanın ona sağlayacağı ayrıcalıklara (sembolik sermaye) sahip olma arzusu ile açılanabilir. Ekonomik kâr, sembolik sermaye edinildikçe oluşacak ve artacaktır. Ekonomik kâr sadece maddi bir kazanım değil, aynı zamanda alanın işleyişini sağlayan kurallar ve yasalar üzerinde de söz sahibi olma, bir nevi egemenlik ilişkisi kurma imkânıdır.

O halde kapitalist üretim mantığında, sanat alanına giren sermaye için her türlü sanat yatırımı formu, alanda kurduğu bir tahakküm biçimi anlamına gelmektedir. Sermaye, iktidar biçimini belirlerken, sanat üreticisini de kuralları sermaye tarafından oluşturulmuş alanın gereklilik ve yükümlülüklerine -açıkça olmasa da - rıza göstermesini, itaat etmesini bekleyerek, kendisine tâbi kılmaktadır. Aslında bu günümüzde hiç de şaşırılacak bir olgu değildir. Harvey bunu iki nedene bağlar ${ }^{73}$;

"Birincisi girişimcilerin yürüttüğü spekülatif ve aynı zamanda önceden kestirilemeyecek çok farklı türden faaliyetler ile kapitalizm koşullarında kültürel, politik, hukuki ve ideolojik değer ve kurumların aynı ölçüde spekülatif gelişmeleri arasında ilke olarak bir fark yoktur. İkincisi, bu öteki alanlardaki kârlılık, uzun süredir bu faaliyetlerin bir parçası haline gelmiş ve zamanla bu bağ zayıflamak bir yana güçlenmiştir. Tam da kapitalizm yayılmacı ve emperyalist olduğu içindir ki, gittikçe daha çok bölgede kültürel hayat para ilişkisinin ve sermayenin dolaşımının mantığının ağına yakalanır”.

Kapitalistler, üretim alanında yaratılan sermayenin aşırı birikimi ve değersizleşme tehdidine karşı oldukça farklı alanlarda yatırıma yönelmektedirler. Çünkü sermaye düzeni sadece üretim, bölüşüm ve tüketim dolayında yani maddi yeniden üretim üzerinden tanımlanamaz, aynı zamanda sembolik, kültürel düzeneklerin de maddi yeniden üretim süreciyle bağlanması gerekir $^{74}$. Bu anlamda sanat alanına yatırım yaparak, bir nevi kültür üreticisi konuma erişmek maddi yeniden üretimin en meşru yollarından biri olacaktır. Çünkü bu alanın parlaklığı, özgeci tavırların gizlice ödüllendirilmesine de yarar.

$\mathrm{Bu}$ husus, Bourdieu’nün yukarıda ifade ettiğim çıkar gütmez çıkarcılık meselesidir. Özellikle sanatsal, bilimsel vb. alanlar gibi evrenlerde, çıkarcı görünmek yerine çıar gütmez görünmenin, bencil görünmek yerine cömert, özgeci görünmenin evrensel olarak daha işe yarar olmasından kaynaklanır ${ }^{75}$. Dolayısıyla dar anlamda sanat alanında, daha genişletirsek kültür üretiminde sermayenin gerek yatırımc1, gerek hami olarak varlık göstermesi sistemin yapısal işleyişini gizlemenin ve ortadaki kâr beklentisini yok saymanın en meşru yolu sayılmalıdır. Çıkar gütmeme

72 Bourdieu P. ve Wacquant L. (2003). Düşünümsel Bir Antropoloji İçin Cevaplar, çev. Nazlı Ökten, İstanbul: İletişim Yayınlar1, s.82-83.

73 Harvey, s.377.

74 Fuat Ercan, s.20.

75 Bourdieu, P. (1995). Pratik Nedenler, çev. Hülya Uğur Tanrı̈ver, İstanbul: Hil Yayınları, s.153. 
altındaki incelikli, gizli çıkarlar; şöhret, isim, marka, unvan, saygınlık, itibar vb. yani tanınmış olmanın sermayesi olan sembolik sermayeye dönüştükçe, hem ekonomik artı - değeri yani maddi yeniden üretimini sağlamayı hem de bu yolla alanda tahakkümü kurmayı becerebilmektedir.

\section{Sonuç}

$\mathrm{Bu}$ çalı̧̧mada sanat nesnesinden ayrıntılı olarak bahsedildi. Nesneye içkin olan kendinden amaçlılı̆̆ı, başka hiçbir nesnede olmayan şeyi sağlamaktadır. Althusser müthiş bir ifadeyle sanatın ayırıcı niteliğini "gerçekliği andıran bir şeyi görmemizi, algılamamızı, duyumsamamızı sağlaması"na bağlar ${ }^{76}$. Bu bireysel olarak sanatın bize ne yaptığı ile ilgilidir. Sanat bizi hakiki olmasa da hakikate en çok benzeyen şeyle hakikate yaklaştırır. Danto ise ayırıcı özelliği daha geniş bir perspektifte değerlendirerek, uluslararası sözsüz bir iletişimin kaynağı olarak görür. Şöyle ifade eder: "Sanat ülkelerin birbirlerine öylesine çok şey aktarabildikleri bir dildir ki, insan bazen sanat olmasaydı bu iletişimin hangi yolla korunabileceğini ve sanatın doğasında, onu böylesi olağanüstü simgeci bir işlevi yerine getirebilmesini olanaklı kılanın ne olduğunu merak eder 77”. Sanat sözsüz bir dildir, bir iletişimdir. Althusser'in gerçekliği andıran şey diye bahsettiğini anlamamız için sanatçının dilini bilmeye gerek yoktur. Sanat, bunu sözsüz iletmektedir. Bu anlamda sanat demokratiktir.

Adorno Benjamin’e yazdığı mektupta şöyle ifade eder: "Yüksek sanat da sınai biçimde üretilmiş tüketici sanat da kapitalizmin damgasını taşır, ikisi de dönüşüm unsurları içerir. Bu ikisi, bir araya geldiklerinde sağlayamadıkları tam bir özgürlüğün birbirinden ayrılmış iki yarısıdır ${ }^{78}$." Bir nevi simya gibi işleyen nesnelerin ya da kavramların üretim alanı olan sanat alanının, kapitalist üretim mantığında değerlendiğini kabul etmekle beraber, sanatın bu düzenle işliyor oluşunun bizi daha umutsuz yaptı̆ğ bir gerçektir. Çünkü bu aslında hiç de "dedikleri kadar" özgür olmadığımızın bir göstergesidir. Belki bize özgürlüğü ifade ettiği için sanat (alanı) bize özgürmüş gibi görünmektedir. Sistemin - bize bunu sadece vaat eden - yapısal isleyişi bunu arzu eder: Özgür olabilirsin! Oysa söz edildiği gibi bu bir tahakküm ilişkisidir ve tahakküm bir elde tutma yöntemidir ki bu da özgürlüğü ihlal etmektedir.

Negri de benzer şekilde, sanat üretiminin kapitalist üretim tarzını taklit ettiğini ve dolayısıyla ona boyun eğdiğini ifade eder ${ }^{79}$. Bu bir boyun eğmeyse eğer, o zaman yeni bir şey üretme/yaratma olanağı kalmış mıdır? Resim, müzik ya da şiir evrenseldirler ve bu evrenselliğini "bir bireyler çokluğu ya da tekil deneyimler tarafından alınan zevkten” alırlar. O zaman piyasa ve özel mülkiyet

76 Althusser, L. (2004). Sanat Üzerine Yazılar, çev. Zühre İlkgelen, İstanbul: İthaki Yayınları, 2004, s.103.

77 Danto, A. C. (1995). Sanat ve Uluslar Söylemi: Ulusların Bienali Üzerine Düşünceler, içinde Orient-ation: Paradoksal Bir Dünyada Sanatın Görünümü, 4. İstanbul Bienali Kitabı, İstanbul: İKSV Yayınları, 1995, s. 55.

78 Adorno, T. W. (2013). Kültür Endüstrisi Kültür Yönetimi, çev. Elçin Gen ve diğerleri, İstanbul: İletişism Yayınları, s.11.

79 Negri, A. (2013). Sanat ve Çokluk, çev. Serkan Sönmezgil, İstanbul: Monokl Yayınları, 2013, s.15. 
sanatın bu özüne ne yapacaktır? Negri, “özel olarak sanatı kendine mal etmenin, sanatı bir fiyata indirgemenin sanatı yok etmek demek olacağını söyler ${ }^{80 ”}$.

O halde belki samimi olarak sormalıyı: Sanat bu dönemde bize ne vaat ediyor? Kapitalist tüketim sistemi kendine alternatif ya da karşı olanı bile kendine içkin hale getirmektedir. Sermaye düzeni önce yapısal bir kapana dönüşmekte ve "kapana dönüştüğü ölçüde, ondan kaçınan ve ona karşı ayakta kalma mücadelesi verenler de sistemi yeniden üretecek mekanizmaları harekete geçirmektedirler ${ }^{81}$ ". Yani, bu sisteme karşı durmak için mücadele eden ne varsa, hangi yöntemler varsa, sistem onları da soğurmakta, kendini yeniden üretecek mekanizmaları karşıtından da üretebilmektedir. Çünkü sistemle başa çıkabilme araçları dahi sisteme dâhil edilmiştir. Kapitalist sistem, sanki bir oyun parkındaymışız gibi, her birimize denetimli alanı içinde özgürlük hissi vaat etmektedir.

Sanat ideolojik ve aynı zamanda muhalif bir alandır. Sanat eserinin sadece belli bir ideolojiyi yansıtmasından ötürü değil, bizatihi ideolojik bir eylem olmasından, çatışmaları sihirli bir değnekle çözmesinden ötürü ${ }^{82}$ sanat ideolojiktir. Bu, Danto’nun ifadesiyle sözsüz, dilsiz iletme sihridir. Ancak sanatın bu uzlaştırıcılığı sermayenin ihtiyaçlarına denk düşer ${ }^{83}$ ve sermaye bu uzlaştırıcılığı kendi imajını tazelemek ve parlatmak için kullanırken, olan bu yolda eleştirelliğini, muhalifliğini kaybeden sanata olmuştur. "Kapitalizmin estetik faaliyetlerde nedeni ilk başta kolay kolay anlaşılmayan olağanüstü bir çoğalmaya sahne olması bundandır 84 ” diye ifade eder Moretti. Bu yönden sanat, belki en ayırt edici özelliklerinden birini kapitalist tüketim kültürüne adeta emanet etmiş ve herhangi tüketim nesnesinden ayırt edilemeyen nesnelerle piyasada yerini almıştır. Böylelikle kapitalist kültürün direttiği hızlı tüketim, sanat ürünleri ve ortamı için geçerlidir. Kültürel ürünler ekonomik ve kültürel bakımdan "birbirlerine benzer ya da en azından iç içe geçip, hiç boşluk bırakmayacak bir sistem oluştururlar” der Adorno ve dolayısıla bir ekonomik sektör olan kültür endüstrisini diğer ekonomik sektörlerden ayırmak mümkün değildir ${ }^{85}$.

Kuşkusuz sanat üreticisi de bu süreçten bağımsız düşünülemez. Hamiye, şirketlere, sponsora, uluslararası sanat organizasyonlarına, seçici sanat kurullarına, sanat ödülleri mekanizmalarına, küratörlere, galerilere tâbi kılındığı küresel bir piyasada sanat yapıtı üretmek durumundadır. Genel anlamıla ifade edecek olunursa, sanat yatırımlarının özel şirketlerin ve patronların imajına olumlu katkılar yaptığı açıktır: Sanat dostu kavramı altında hayırsever, fedakâr, verici, modern, aydın bir kişi ve kurum kimliği yatmaktadır. Bir nevi burjuva kimliğidir bu. Sermayeye giydirilen bu kimlikler, sermayeye yaradığı gibi sistemi yeniden üretmeye de yarar. Hem de artan

80 Negri, s.45.

81 Ercan, s. 21.

82 Foster, H. (2008). Kültürel Direniş, çev. Elçin Gen, Sanat, Siyaset, Kültür Çağında Sanat ve Kültürel Politika içinde, Ed. Ali Artun, İstanbul: İletişim Yayınları, s.155-183.

83 Foster, s.156.

84 Moretti, F. (2005). Mucizevi Göstergeler - Edebi Biçimlerin Sosyolojisi Üzerine, çev. Zeynep Altok, İstanbul: Metis Yayınlar1, s.41-42.

85 Adorno, 2013, s.109-111. 
bir hayranlık ve kitlesel bir bağlılık duygusu ile sistem yeniden yaratılır. Bu yaratılan imajlar Ercan’n ifadesine göre, sistemin yapısal işleyişini ve bu yapısal olanın oluş sürecini gözlerden gizler ve gizlediği ölçüde sistemin zihinlerde yeniden üretilmesine yol açar ${ }^{86}$.

Sanat artık o kadar stratejik bir alandır ki, kişiler, şirketler kadar sanat kurumları da bundan faydalanmaktadır. İngiltere Sanat Konseyi, herkese iyi sanat sağlamaya yönelik bir stratejik raporda sanatın işlevselliğinden yararlanarak kısa ve uzun vadede hedefler hazırlamıştır. $\mathrm{Bu}$ raporda sanatın insanları düşündürdüğüne, insanların kendilerini kişisel ve siyasi olarak ifade etmelerine, fikirlere ve dünyaya meydana okumalarına yaradığına dikkat çekilir ${ }^{87}$. Ama daha da önemlisi raporun sonunda yer almaktadır: Sanat bize "dünyada yapılacak ne kaldığını hatırlatır". $\mathrm{Bu}$ çok güzel ama bir o kadar da sorgulamaya açık bir ifadedir.

Çünkü sanat-çı dünyada yapılacak ne kaldığını sisteme uyum göstererek, piyasanın kurallarına göre oynayarak, kurumların sanatçısı olmaya rıza göstererek, bu değerleme mekanizmasına girmeyi kabul ederek yapamaz. Özerkliğini bu mübadele sistemine feda ederek de yapamaz. Sanat "ideoloji olarak verili topluma karşı çıkar" der Marcuse ve ekler "Sanatın özerkliği buyurur: Şeyler değişmelidir"88. Sanat toplumu sarsarak onu dönüştürücü bu niteliğini tüketim kültürüne teslim etmiş, toplumsal bir niteliğini unutmayı seçmiştir. Marcuse’ün ifadesiyle "sanatın özerkliği özgürlüksüz toplumda bireylerin özgürlük yoksunluklarını yansıtır ${ }^{89}$ ". Sanat özgürmüşüz hissini yüceltmek yerine, bir ayna gibi olup, en azından, özgür olmadığımız konusunda bir olduğumuzu belki bize hatırlatmalıdır. Bu anlamda sanatın özerkliği birleştirici ve dayanışmacıdır da aynı zamanda. "Özerk, bireysel kararda köken bulur; kitleleri değil özgürce bir araya gelen bireyleri birleştirir ${ }^{90 "}$ der Marcuse. Ve bunun sonu tabii ki sanatın siyasiliğine dayanır. Sanat eseri ancak özerk olduğunda politik bir ifade kazanır ${ }^{91}$. Sadece politik söylem üreterek politik olunmaz. Yoksa özellikle bienal sanatçıları olmak üzere birçok sanatçının politik işler ürettiği söylenebilirdi. Ancak politik işler ürettiğini söyleyen sanatçılar bile, ürettikleri işlerinde karşı oldukları sistemi üreten kurumlarca desteklenebildiklerini ya bilmemekte ya da göz ardı etmektedirler ${ }^{92^{\star}}$. Söylemde politik olmanın yanında başka unsurlar da gerekmektedir. Rancière Estetiğin Siyaseti’nde der ki ${ }^{93}$ :

"Sanat toplumsal ve siyasi meselelerle ilgili mesajlar ve duygular ileterek siyasi olmaz. Toplumsal yapıları, çatışmaları ya da kimlikleri yansıtma biçimiyle de siyasi olmaz. Tam da bu işlevlere aldığı

86 Ercan, 25.

87 The Art Council, Achieving Great Art for Everyone: A Strategic Framework For The Arts, London: Art Council England Publication, 2010.

88 Marcuse, H. (1997). Estetik Boyut - Sanatın Sürekliliği: Marksist Estetiğin Bir Eleștirisine Doğru, çev. Aziz Yardıml, İstanbul: İdea Yayınları, s.22.

89 Marcuse, 1997, s.62.

90 Marcuse, 1997, s.39.

91 Marcuse, 1997, s.48.

92 *Bkz. Kösemen, İ. B. (2014). Kurumsal Yatırım Aracı Olarak Sanat, İktisat Dergisi, Çağdaş Sanat ve Sermaye, No.526: 28-39.

93 Rancière, J. (2008). Estetiğin Siyaseti, çev. Elçin Gen, içinde Sanat, Siyaset, Kültür Çağında Sanat ve Kültürel Politika, Ed. Ali Artun, İstanbul: İletişim Yayınları, s.208. 
mesafe yoluyla siyasi olur. [...] Sanat bir ortaklık duyusunda birleşme tarzını yeniden düzenleyen görünürlük formlarını biçimlendirdiği ölçüde siyasidir.”

Sanatçılar, kurumlarla bu mesafeyi hatırlamalıdır. Ama en önemlisi güçlerini hatırlamalıdırlar. Sanat nesnesinin gerçekten ne olduğunu hatırlamaya ve bizlere tekrar hatırlatmaya ihtiyaçları vardır. Çünkü Bourdieu’nün dediği gibi, sanatsal alan bir iktidar alanıdır, ama aynı zamanda bu iktidar alanını dönüştürmeye ya da muhafaza etmeye çalışan bir mücadele alanıdır ${ }^{94}$. Bu mücadele alanında sanatçı artık burjuvazinin çıkarlarını temsil etmekle mükellef olmadığını ${ }^{95}$ da hatırlamalıdır. Bunları ifade ederken sanatın sisteme içkin olduğunu kabul ediyorum ve tam da oradan hareketle tekrarlamakta bir beis görmüyorum: "Sanat kaçınılmaz olarak var olanın parçasıdır ve ancak var olanın parçası olarak var olana karşı konuşur ${ }^{96 ” . ~}$

Günümüz sanatında dünyanın en önemli zincir galerilerinden ${ }^{97^{*}}$ birinin sahibi ve sanat simsarı Gagosian’ın sanatta çok kazanan olduğunu ${ }^{98}$ muştuladığı, sanat tarihindeki 'en yaratıcı eserleri' belirleyebilen programın geliştirildiği ${ }^{99}$, yapay zekânın yaptı̆̆ 1 tablonun 432 bin dolara satıldığ $100^{\star} 101$, performans sanatlarının da satın alınıp, koleksiyonunun yapılabildiğ ${ }^{102}$ bir döneme tanıklık ediyoruz.

Bu alan öyle bir alandır ki, küresel borsalardaki ya da dünya ekonomik konjonktüründe yaşanan tüm dalgalanmalar, sanat piyasasının değerini düşürmek bir yana değerini artırmaktadır. Bunun cevabı çağdaş sanat piyasasını etkileyen küresel aktörlerde aranmalıdır. Ben bunu, çalışmamda, sanat eserine içkin olan şeyle, onun aurasıyla ve kendinden amaçlılığıyla anlatmaya çalıştım - ki bu sanatın özerkliğini sağlamaktadır.

94 Bourdieu, P. (1993). The Field of Cultural Production - Essays on Art and Literature, US: Columbia University Press, s.30

95 Foster, s.162.

96 Marcuse, 1997, s. 40.

97 * $\mathrm{Bu}$ anlamda sanat galerilerini 'Starbucks'laştırmasıyla ünlüdür. "Why Gagosian is the Starbucks of the art world and the saviour",

https://www.theguardian.com/artanddesign/jonathanjonesblog/2014/mar/24/larry-gagosian-art-galleries, (Erişim tarihi: 10.08.2018)

98 Larry Gagosian : "En art, il y a beaucoup de gagnants", http://www.lefigaro.fr/arts-expositions/2018/10/22/03015.201.81022ARTFIG00165-larry-gagosian-en-art-il-y-abeaucoup-de-gagnants.php, (Erişim tarihi: 12.07.2018)

99 "Sanat Tarihinde Devrim Niteliğinde Gelişme", https://www.sozcu.com.tr/2015/dunya/sanat-tarihinde-devrimniteliginde-gelisme-856780/ (Erişim tarihi: 02.09.2018)

100 *Sanat eseri ile teknolojinin ve dijitalleşmenin ilişkisi yeni ve ilginç bir konudur. Dijital emeğin sanat üretim aşamasını etkilemeye başladığı ve bundan sonra daha da etkileyeceği çok açıktır. Ancak bu konu, başka bir çalışmamın konusu olacaktır.

101 “İmza 'min max $\operatorname{Ex}[\log (\mathrm{D}(\mathrm{x}))]+\mathrm{Ez}[\log (1-\mathrm{D}(\mathrm{G}(\mathrm{z})))]$ ': Yapay zekanın yaptığı portre 432 bin dolara satıldı”, http:// www.diken.com.tr/imza-min-max-exlogdx-ezlog1-dgz-yapay-zekanin-yaptigi-portre-432-bin-dolara-satildi/, (Erişim tarihi: 12.09.2018)

102 “Can You Buy Performance Art?", https://www.ft.com/content/615f09ba-bfef-11e8-84cd-9e601db069b8 (Erişim tarihi: 01.10.2018) 
Şimdilerde yaşanan, bu özerkliğin, çağdaş sanat piyasasını kontrol eden sosyal, ekonomik sermayenin görece zenginlerinin hükmüne geçmesidir. Finans-kapital devrinin en önemli temsilcileri, sanat dünyasının önemli temsilcileriyle işbirliği halinde sanat piyasasını da kontrol eder olmuştur. Kapitalist üretim süreci içinde, sermaye birikiminin sekteye uğradığ 1 kriz zamanlarında, sanat alanının göz alıcı, prestijli, markaya itibar katan özelliği kullanılmaktadır. Böylece bir yandan azalan kârlar telafi edildiği gibi, bir yandan da şirketlerin topluma zararlı faaliyetleri konuşulmaz olmakta, olumsuz kurum imajı olumluya dönmektedir. Öyle ki en başta verdiğim örnekten hatırlanacağı gibi, sanatçının kapitalist üretim sürecine yaptığı bir eleştiri bile eserin değerinin ve tabii ki ona sahip olanın da kazancının artmasına neden olmaktadır. Dolayısıyla ekonomik krizler, çağdaş sanat alanı ve yatırımcıları için kayıp değil, kazanç yaratabilmektedir.

Bu dönemde artık sanat üretmek için tüm sanat üreticilerinin daha cesur davranıp, tüm kurum kimliklerini ve birer ayrıcalık gibi sunulan sermaye tarafından -alenen ya da zımni - temsiliyeti reddetmelerinin zamanıdır. Çünkü özgür düşünce, sanata içkin olan o şey sayesinde kazanılan özerklik, krizleri firsata çevirmenin bir yolu olarak sanatı -da - kullanan sermeyenin tehdidi altındadır.

\section{Kaynakça}

ADORNO, T. W. (1997). Prisms, Cambridge: MIT Press, 9. Baskı.

ADORNO, T. W. (2013). Kültür Endüstrisi Kültür Yönetimi, çev: E. Gen ve diğerleri, İstanbul: İletişim Yayınları.

ALTHUSSER, L. (2004). Sanat Üzerine Yazılar, çev: Z. İlkgelen, İstanbul: İthaki Yayınları.

ALTUĞ, T. (2007). Kant Estetiği, İstanbul: Payel Yayınları, 2. Baskı.

ARP, H. (2018). "Dadaland”, içinde Dada Kılavuz 1913-1923 Münih, Zürih, Berlin, Paris, çev. N. Artun Altınyıldız ve diğerleri, İstanbul: İletişim Yayınları.

ARTUN, A. (2014) Sanatın Özerkliği Üzerine, http://www.e-skop.com/skopbulten/sanatin-ozerkligiuzerine/1749 (Erişim Tarihi: 10.06.2018)

ARTUN ALTINYILDIZ, N. ve Artun, A. (2018). Dada Kılavuz, 1913-1923 Münih, Zürih, Berlin, Paris, çev. N. Artun Altınyıldız ve diğerleri, İstanbul: İletişim Yayınları.

BALL, H. (2017). “Dada Manifestosu”, içinde Fütüristlerden Stuckistlere 100 Sanatçı Manifestosu, der. Alex Danchev, çev. M. E. Uslu, İstanbul: Espas Yayınları.

BAUDRILlARD, J. (2004). Gösterge Ekonomi Politiği Hakkında Bir Eleştiri, çev. O. Adanır, A. Bilgin, İstanbul: Boğaziçi Üniversitesi Yayınları.

BENJAMIN, W. (1969). Illuminations, NY: Schocken Books.

BENJAMIN, W. (1995). Estetize Edilmiş Yaşam - Sanattan Savaş ve Siyasete Alman Faşizminin Kuramları, çev. Ü. Oskay, İstanbul: Der Yayınları.

BOCCIONI, U. (2017). "Fütürist Ressamlar Manifestosu”, içinde Fütüristlerden Stuckistlere 100 Sanatçı Manifestosu, der. Alex Danchev, çev. M. E. Uslu, İstanbul: Espas Yayınları.

BOURDIEU, P. (1993). The Field of Cultural Production - Essays on Art and Literature, US: Columbia University Press.

BOURDIEU, P. (1995). Pratik Nedenler, çev. H. Uğur Tanrı̈̈ver, İstanbul: Hil Yayınları. 
BOURDIEU, P. (2002). Sanatın Kuralları, çev. N. K. Sevil, İstanbul: YKY.

BOURDIEU, P. ve Wacquant, L. (2003). Düşünümsel Bir Antropoloji İçin Cevaplar, çev. N. Ökten, İstanbul: İletişim Yayınları.

BRETON, A. (1925). "La Dernière Grève”, La Révolution Surréaliste, No. 2 (1-3).

BÜRGER, P. (2003). Avangard Kuramı, çev. E. Özbek, Ş. Öztürk, İstanbul: İletişim Yayınları.

CALHOUN, C. (2007). Bourdieu Sosyolojisinin Ana Hatları, der. Güney Çeğin ve diğerleri, içinde Ocak ve Zanaat: Pierre Bourdieu Derlemesi İstanbul: İletişim Yayınları.

DANCHEV, A. (2017). (der.) Fütüristlerden Stuckistlere 100 Sanatçı Manifestosu, çev. M. E. Uslu, İstanbul: Espas Yayınları.

DANTO, A. C. (1995). Sanat ve Uluslar Söylemi: Ulusların Bienali Üzerine Düşünceler, içinde Orient-ation: Paradoksal Bir Dünyada Sanatın Görünümü, 4. İstanbul Bienali Kitabı, İstanbul: İKSV Yayınları.

DEBORD, G. (2017). “Sitüasyonist Manifesto”, içinde Fütüristlerden Stuckistlere 100 Sanatçı Manifestosu, der. Alex Danchev, çev. M. E. Uslu, İstanbul: Espas Yayınları.

ERCAN, F. (2006). Sermayeyi Haritalandırmaya Yönelik Kavramsal Düzenekler, Praksis, No.19: 9-53.

FOSTER, H. (2008). Kültürel Direniş, Çev: E. Gen, içinde Sanat, Siyaset, Kültür Çağında Sanat ve Kültürel Politika, Ed. Ali Artun, İstanbul: İletişim Yayınları.

GERMANER, S. (1991). “Osmanlı İmparatorluğu’nun Uluslararası Sergilere Katılımı ve Kültürel Sonuçları”, Tarih ve Toplum, C.16 (95): 33-40.

HARVEY, D. (2006). Postmodernliğin Durumu, İstanbul: Metis Yayınları, 4. Baskı.

HOPKINS, D. (2006). Dada ve Gerçeküstücülük, Çev. S.K. Angı, Ankara: Dost Kitabevi.

HUYSSEN, A. (1981). “The Search for Tradition: Avant-Garde and Postmodernism in 1970's”, New German Critique, No:22(1): 23-40.

JAY, M. (2005). Diyalektik İmgelem-Frankfurt Okulu ve Toplumsal Araştırmalar Enstitüsünün Tarihi (1923-50), çev. Ü. Oskay, İstanbul: Belge Yayınları, 2. Baskı.

JUSDANIS, G. (1998). Gecikmiş Modernlik ve Estetik Kültür - Milli Edebiyatın İcat Edilişi, çev. T. Birkan, İstanbul: Metis Yayınları.

KANT, I. (2011). Yargı Yetisinin Eleştirisi, çev. A. Yardımlı, İstanbul: İdea Yayınları, 2. Baskı.

KÖSEMEN, İ. B. (2012). “Nesne ile Meta Arasında Sanat”, M.Ü. İktisat Fakültesi Dergisi, 33(2): 205-220.

KÖSEMEN, İ. B. (2014). "Kurumsal Yatırım Aracı Olarak Sanat”, İktisat Dergisi, Çağdaş Sanat ve Sermaye, No.526: 28-39.

KREFT, L. (2008). Sanat ve Siyaset: Sanatın Siyaseti ve Siyaset Sanatı, çev. E. Gen, içinde Sanat, Siyaset, Kültür Çağında Sanat ve Kültürel Politika, Ed. Ali Artun, İstanbul: İletişim Yayınları, 2008.

LAZZARATO, M. (2017). Marcel Duchamp ve İşin Reddi, çev. S. Çalcı, İstanbul: Kolektif Kitap.

LEADER, D. (2004). Mona Lisa Kaçırıldı - Sanatın Bizden Gizledikleri, çev. H. Akdemir, İstanbul: Ayrıntı Yayınları.

MACIUNAS, G. (2017). “Fluxus Manifesto”, içinde Fütüristlerden Stuckistlere 100 Sanatçı Manifestosu, der. Alex Danchev, çev. M. E. Uslu, İstanbul: Espas Yayınları.

MARCUSE, H. (1991). Karşıdevrim ve Başkaldırı, çev. G. Koca ve V. Ersoy, İstanbul: Ara Yayıncılık.

MARCUSE, H. (1997). Estetik Boyut - Sanatın Sürekliliği: Marksist Estetiğin Bir Eleştirisine Doğru, çev. A. Yardımlı, İstanbul: İdea Yayınları.

MARINETTI, F. T. (2017). “Fütürizmin Kuruluşu ve Fütürist Manifesto”, içinde Fütüristlerden Stuckistlere 100 Sanatçı Manifestosu, der. Alex Danchev, çev. M. E. Uslu, İstanbul: Espas Yayınları. 
MAROIN, D. ve diğerleri, (2017). “'Arap Sürrealist Hareketi Manifestosu, içinde 100 Sanat Manifestos, der. Alex Danchev, çev. M. E. Uslu, İstanbul: Espas Yayınları.

MARX, K. ve Engels, F. (1995). Sanat ve Yazın-I, çev. Ö. Ünalan, İstanbul: Sol Yayınları.

MENKE, C. (2018). Özerkliğin Ötesi, http://www.e-skop.com/skopbulten/ozerkligin-otesi/3813 (Erişim Tarihi: 20.09.2018)

MILLET, C. (2006). L'Art Contemporain - Histoire et Géographie, Paris: Flammarion.

MORETTI, F. (2005). Mucizevi Göstergeler - Edebi Biçimlerin Sosyolojisi Üzerine, çev. Z. Altok, İstanbul: Metis Yayınları.

NEGRI, A. (2013). Sanat ve Çokluk, çev. S. Sönmezgil, İstanbul: Monokl Yayınları.

POLAT, N. (2017). Sınırları Aşındırmak - Modernizm ve Çağdaş Sanat Üzerine, İstanbul: Belge Yayınları.

RANCIERE, J. (2008). Estetiğin Siyaseti, çev. E. Gen, içinde Sanat, Siyaset, Kültür Çağında Sanat ve Kültürel Politika, Ed. Ali Artun, İstanbul: İletişim Yayınları.

RUBY, F. (1998). “Théophile Gautier et La Question de L’Art Pour L’Art”, içinde Bulletin de la Société Théophile Gautier, Montpellier, http://www.theophilegautier.fr/wp-content/uploads/2015/02/ BSTG20.pdf (Erişim Tarihi: 10.09.2018)

SORGUÇ, G. (2017). “Sanata Karşı Başkaldırı: Avangard”, FLSF (Felsefe ve Sosyal Bilimler Dergisi), Güz, say1: $24: 37-56$.

STALLABRASS, J. (2009). Sanat A.Ş. - Çağdaş Sanat ve Bienaller, çev. E. Soğancılar, İstanbul: İletişim Yayınları.

TEKDEMİ, A. (2013). “1867 Paris Sergisi ve Sultan Abdulaziz’in Sergiyi Ziyareti”, Trakya Üniversitesi Edebiyat Fakültesi Dergisi, 3(6): 1-19.

THE ART COUNCIL, (2010). "Achieving Great Art for Everyone: A Strategic Framework For The Arts", London: Art Council England Publication.

TRISTAN T, (2017). “Dada Manifestosu”, içinde Fütüristlerden Stuckistlere 100 Sanatçı Manifestosu, der. Alex Danchev, çev. M. E. Uslu, İstanbul: Espas Yayınları.

YOSHIHARA, J. (2017). “Gutai Manifesto”, içinde Fütüristlerden Stuckistlere 100 Sanatçı Manifestosu, der. Alex Danchev, çev. M. E. Uslu, İstanbul: Espas Yayınları.

WU, C. (2005). Kültürün Özelleştirilmesi-1980’ler Sonrasında Şirketlerin sanata Müdahalesi, çev. E. Soğancılar, İstanbul: İletişim Yayınları.

https://www.theguardian.com/artanddesign/jonathanjonesblog/2014/mar/24/larry-gagosian-art-galleries (Erişim Tarihi: 10.08.2018)

http://www.lefigaro.fr/arts-expositions/2018/10/22/03015.201.81022ARTFIG00165-larry-gagosian-en-artil-y-a-beaucoup-de-gagnants.php (Erişim Tarihi: 12.07.2018)

https://www.sozcu.com.tr/2015/dunya/sanat-tarihinde-devrim-niteliginde-gelisme-856780/ (Erişim Tarihi: 02.09.2018)

http://www.diken.com.tr/imza-min-max-exlogdx-ezlog1-dgz-yapay-zekanin-yaptigi-portre-432-bindolara-satildi/ (Erişim Tarihi: 12.09.2018)

https://www.ft.com/content/615f09ba-bfef-11e8-84cd-9e601db069b8 (Erişim Tarihi: 01.10.2018)

https://www.theguardian.com/artanddesign/2018/oct/06/banksy-sothebys-auction-prank-leaves-artworld-in-shreds-girl-with-balloon, (Erişim Tarihi: 12.10.2018) 


\section{Extended Abstract}

Since the 1980's, capital has made every field a surplus value for itself by swallowing each obstacle standing in front of internationalisation. Now, what we are talking about is global capitalism. The pillar of creating global cultural discourse for the global capitalism has started to be created through companies that use art through marketing. Of course, it is not coincidence that privatisation policies lead by Reagan and Thatcher in America and England in the beginning of 1980's also reflected on the field of culture and art. By the 80's, companies have both intensified their art collecting operations and transformed art museums and galleries into their public relations tools. In this regard, legal basis for art sponsorship has been developed, and the importance of creating a "cultured, progressive, contemporary" image for a company has been comprehended in order to repair damaged image of an institution during the 1970's. Another momentum was gained when entering the 90's. The end of Cold War caused another change for the art world. Now, the issue in question is the globalised art that is arm in arm with global capitalism, and of course this created the phenomenon of the institutionalisation of global art. International art biennials and art fairs are the best examples of this.

All ideological fields that are cultural and artistic are now being formed within capitalist mindset. Therefore, can art be separated from the commodity production process of capital's purpose of creating surplus value? Of course not. According to Bourdieu, even the fields that seem to be disinterested in economic interests (art, literature, science, etc.) operate according to accumulation of capital and capital's reproduction logic. However, the interest in these fields cannot be seen crystal clear as it is in economic fields. For this reason, it is customary for capital involved in this field to ignore what is economical. Bourdieu summarises this as "as much as the economical one is ignored, that much of a belief in the disinterestedness settles". Because economic capital can gather the specific profits, and the yield to maturity of the field only when it transforms into a symbolic capital; that symbolic capital, as known, is the capital that contains all other capital forms (economic, social and cultural) within itself and it is a capital of having a say in the field and being known. In that case, any kind of investment in art for capital means a form of domination within the logic of capitalist production. While capital determines the form of power, by way of expecting art producer's consent - though not explicitly-to the rules and the requirements of the field created by capital itself, it subordinates the art producer.

The thing that defines arts is that it's purpose is itself and, this means autonomy. The difference of an artwork might be the following. It has an intrinsic value; a value in itself. From this point of view, Kant states that the creator of the artwork does not have any other purpose but the artwork itself. Through this inherent "thing" / intrinsic value, the object is no more an object and it becomes the object: the object of art.

Capitalists go towards quite different fields for investment, because of over-accumulation of capital and the threat of depreciation. Because, the system of capital cannot be described only in terms of production, distribution and consumption; symbolic and cultural mechanisms should 
also be connected with the re-production process. Well, in such a process, what can art promise? And what can the artist claim? In this case, can we talk about the autonomy of art? In other words, according to Benjamin, in the age of mechanical reproduction, when the cultic value of the art object is replaced with the display (exhibition) value, the inherent thing, the self - purposed nature, or with his terms, "the aura" of the work of art, can it still be the case?

The debate on autonomy is not new; the anti-political view, which presented a radical critique of the capitalist system in the 19th century, was replaced by the Avangardian Model in the 20th century and offered clearly disobedience to the artists. In this study, examples of the invitation to disobedience will be seen through art manifestos. However, although the debate is old, the situation in the neo-liberal world of the 21 st century is quite different at this point, as it is mentioned at the beginning of the summary. For this reason, it is urgent for all art workers, especially the artists, to carefully adjust their distances with capital(ists) and institutions and to create new forms of production and spaces to preserve that inherent thing in their works. Institutionalized art should be rejected by artists first. In this sense, it's essential that the artists or art workers should incorporate new methods of political and collective artistic production to resist the institutionalized art that is under the control of the capital. This study demands the existence of a field of struggle against the current political economy of art. Otherwise, with Negri's expressions, it can be argued that if art imitates the capitalist mode of production, if it obeys, and if it is reduced to the price, to the market, to the capital and to the relationship between them, it will disappear. 